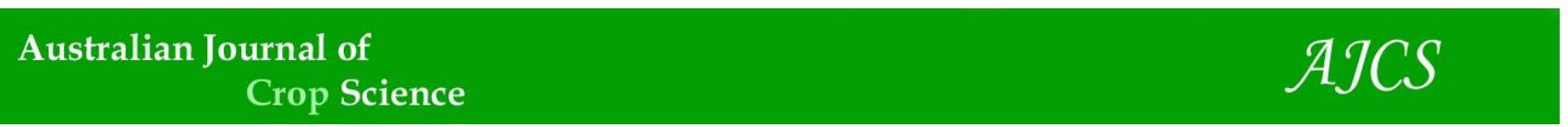

AJCS 14(10):1623-1629 (2020)

ISSN:1835-2707

doi: 10.21475/ajcs.20.14.10.p2400

\title{
Drying kinetics of Hyola 430 hybrid canola (Brassica napus L.) seeds
}

\author{
Lílian Moreira Costa ${ }^{1}$, Osvaldo Resende ${ }^{1}$, Daniel Emanoel Cabral de Oliveira ${ }^{2}$, José Mauro Guimarães \\ Carvalho $^{2}$, Sarah Gabrielle Sousa Bueno ${ }^{2}$, Wellytton Darci Quequeto ${ }^{1 *}$
}

\author{
${ }^{1}$ Instituto Federal de Educação, Ciência e Tecnologia Goiano, Campus Rio Verde, Goiás, Brazil \\ ${ }^{2}$ Instituto Federal de Educação, Ciência e Tecnologia Goiano, Campus Iporá, Goiás, Brazil
}

*Corresponding author: wellytton_quequeto@hotmail.com

\begin{abstract}
This work aimed to study the drying kinetics of canola seeds, fit mathematical models and obtain the effective diffusion coefficient. Canola seeds with initial moisture content of 0.3653 (decimal, d.b.) were subjected to drying in a forced ventilation oven at temperatures of $40,60,80$ and $100{ }^{\circ} \mathrm{C}$ and relative humidity of $37.15,16.93,8.35,4.41$ and $2.47 \%$, respectively. The samples were dried on trays without perforations, containing approximately $77 \mathrm{~g}$, in three replicates. A final moisture content of $0.080 \pm 0.004$ (decimal, d.b.) was established to determine the drying curves and fit the mathematical models. The mathematical models were selected considering the mean estimated error, chi-square, coefficient of determination, mean relative error, and Akaike (AIC) and Bayesian (BIC) information criteria. Drying time decreased with increasing temperature. Based on the best values of the statistical parameters and together with the Akaike and Bayesian information criteria, the Page model was selected to represent the drying kinetics of canola seeds. The effective diffusion coefficients showed magnitudes between $0.153 \times 10^{-11}$ and $1.221 \times 10^{-11}\left(\mathrm{~m}^{2} \mathrm{~s}^{-1}\right)$, and their values increased with temperature increase, being described by the Arrhenius equation, with activation energy of $33.94 \mathrm{~kJ}$ $\mathrm{mol}^{-1}$, an important piece of information to consider when designing drying equipment.
\end{abstract}

Keywords: desorption, mathematical modeling, oilseed, postharvest.

Abbreviations: db_dry basis; g_gramme; h_hour; AIC_akaike information criterion; BIC_schwarz's bayesian information criterion; SE_mean estimated error; $\chi_{-}^{2}$ chi-square test; $R^{2}$ adjusted coefficient of determination; $P_{-}$mean relative error.

Introduction

Canola (Brassica napus L.) is an oilseed plant belonging to the Brassicaceae family and has stood out as an important alternative species to produce seeds and grains in the winter period in the southern region of Brazil (Krüger et al., 2011). Its seed has around $15 \%$ protein and $40 \%$ oil (Norton and Harris, 1975), being a promising source of renewable energy (Singh, 2011), as well as excellent nutritional quality for human and animal consumption (Lin et al., 2013; Bergamin et al., 2011).

Given the economic potential of this crop, up to the present time several studies have been carried out on aspects such as yield (Rosa et al., 2011), adaptation (Lima et al., 2017), cultivation (Fard et al., 2018), irrigation (Sanches et al., 2014) and oil quality (Fleddermann et al., 2013). However, there is limited information on the postharvest of this species.

Mathematical models allow evaluating and predicting the behavior of various materials during the drying process, being described by theoretical, semi-theoretical and empirical equations. According to Corrêa et al. (2011), fitting mathematical models to experimental data is essential to predict and simulate the behavior of products subjected to a given process. For simulation, whose principle is based on the drying of successive thin layers of the product, a mathematical model that satisfactorily represents the water loss of the product during the process is used (Berbert et al., 1995). Therefore, using mathematical models for drying contributes to the execution of projects and sizing of equipment.

Drying equipment should be designed considering the following criteria: (i) the dryer must provide sufficient heat for the evaporation of moisture from the samples, (ii) appropriate air flow must be provided to eliminate moisture in the dryer, (iii) the surrounding conditions should not reduce the quality of the product, and (iv) adequate time required for satisfactory drying of the material should be used (Avhad and Marchetti, 2016).

In recent years, there have been scientific efforts to investigate the influence of different temperatures on the drying kinetics of several products, such as soybean grain (Botelho et al., 2018); Piper umbellatum L. leaves (Dorneles et al., 2019); Jatropha curcas L. seeds (Keneni et al., 2019); sunflower grains (Smaniotto et al., 2017); peanut fruit (Araujo et al., 2017); cowpea seeds (Camicia et al., 2015).

Among the different indices used to evaluate the drying kinetics of agricultural products, one of the most important is the diffusion coefficient. This index makes it possible to evaluate and compare the drying rate of products with different sizes, shapes and textures (Botelho et al., 2015).

Therefore, this study aimed to describe the drying behavior of canola seeds, by fitting different mathematical models to the experimental drying data, select the one which best represents the phenomenon, and determine the effective 
diffusion coefficient and the activation energy of the process.

\section{Results and Discussion}

\section{Drying time}

The times required for canola seeds to reach the moisture content of $0.080 \pm 0.004$ (d.b.) were 10.83, 4.87, 2.17 and $1.5 \mathrm{~h}$ for the drying temperatures of $40,60,80$ and $100{ }^{\circ} \mathrm{C}$, respectively. This result shows that the increase in air temperature leads to reduction in the drying time of the seeds, so the moisture content ratio decreases abruptly with the increase in drying temperature (Figure 1).

\section{Mathematical modeling}

The mathematical models had high coefficients of determination, above 0.99 (Table 1). Models with high coefficients of determination indicate a satisfactory representation of the drying process. It is worth pointing out that the models with highest coefficients of determination were Wang and Singh, Page and Midilli, regardless of the temperature studied. When analyzed alone, the coefficient of determination $\left(R^{2}\right)$ does not constitute a good criterion to select nonlinear models (Madamba et al., 1996). Thus, the values for the mean estimated error, chi-square and mean relative error were considered.

In relation to the mean estimated error (SE), all models had values below 0.0267 , which is satisfactory for their good fit to the experimental data. It is also verified that, among the analyzed models, the lowest value for chi-square test $\left(\chi^{2}\right)$ was obtained by the Page model, while the highest values were obtained by the Thompson and Two-term exponential models, and the higher the value of $\chi^{2}$, the greater the discrepancy between the experimental values and the expected values (Molina Filho et al., 2006). Thus, the chisquare value is related to the quality of the model fit to the experimental data. In general, the models of Wang and Singh, Page and Midilli showed the lowest values of chisquare.

It should be pointed out that, for the models to adequately represent the drying phenomenon, the mean relative error (P) should be lower than $10 \%$ (Mohapatra and Rao, 2005). Thus, all the models evaluated in this study satisfactorily represent the drying kinetics. However, Wang and Singh, Page and Midilli had the lowest mean relative errors at all

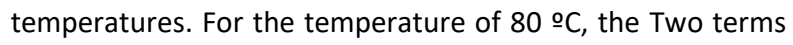
and Approximation of Diffusion models also stood out.

Considering the lowest values of AIC and BIC for one of the selection criteria (Table 2), it can be noted that the Page model showed the lowest values. Based on that and on the fitting criteria analyzed previously, this model was the best fitted to the experimental data, hence being selected to represent the desorption curves of canola seeds.

Several criteria can be used to fit mathematical models to drying data, and AIC and BIC constitute an additional method to strengthen and endorse the decision-making. Several studies have been conducted nowadays and also satisfactorily indicate the use of AIC and BIC to select the best mathematical model to predict postharvest processes, such as: drying of the crushed mass of 'jambu' (Acmella oleracea) (Gomes et al., 2018); determination of sorption isotherms of Hymenaea stigonocarpa Mart. seeds (Ferreira
Junior et al., 2018); drying kinetics of biofortified pulp of sweet potato (Ipomoea batatas Lam.) (Souza et al., 2019); and drying kinetics of leaves of spiked pepper (Piper aduncum L.) (Quequeto et al., 2019).

The drying curves of canola seeds estimated by the Page model are presented in Fig. 2. This model satisfactorily fitted to the experimental values obtained during the drying of canola seeds, demonstrating that the moisture content at the beginning of the process is exponentially reduced to a final moisture content of $0.080 \pm 0.004$ (d.b.). At the end of the drying, the interaction between water and dry matter becomes stronger as the moisture content of the product decreases (Siles et al., 2015). It is observed in the present study that the drying time is directly associated with air temperature and that the reduction of moisture content is faster at the beginning of the drying process.

The parameters " $k$ " and " $n$ " of the Page model were significant at $1 \%$ probability level by t-test at all temperatures analyzed. The values of these parameters are represented in Eqs. 12, 13, 14 and 15 for the temperatures of $40,60,80$ and $100{ }^{\circ} \mathrm{C}$, respectively.

$\mathrm{RX}=\exp (-0.161556 \times$
$\left.40^{1.058301}\right)$

$\mathrm{RX}=\exp (-0.325076 \times$

$\left.60^{1.076186}\right)$

$\mathrm{RX}=\exp (-0.732860 \times$

$\left.80^{1.136222}\right)$

$\mathrm{RX}=\exp (-1.163299$

$\times 100^{1.149194}$ )

It can be observed that the magnitude of the drying constant (k), which represents the effect of the external drying conditions, increased with the increment in drying air temperature. The drying constant $(\mathrm{k})$ can be used as an approximation to characterize the effect of temperature and is related to the effective diffusivity in the drying process in the falling rate period and to the liquid diffusion which controls the process (Madamba et al., 1996; Babalis and Belessiotis, 2004).

\section{Effective diffusion coefficients (D)}

During the drying process, the effective diffusion coefficients (D) showed magnitudes from $0.153 \times 10^{-11}$ to $1.221 \times 10^{-11}$ $\mathrm{m}^{2} \mathrm{~s}^{-1}$ and their values increase with the increment in drying air temperature (Fig. 3). The values of the diffusion coefficient calculated for canola seeds are consistent with those reported in the literature for the drying of agricultural products, which range from $10^{-9}$ to $10^{-11} \mathrm{~m}^{2} \mathrm{~s}^{-1}$ (Madamba et al., 1996).

The effective diffusion coefficient of canola seeds increased linearly with the increment in drying air temperature, demonstrating a greater intensity of the phenomenon of water transport from the interior to the periphery of the seed, corroborating the results obtained by other researchers (Botelho et al., 2015; Smaniotto et al., 2017; Quequeto et al., 2019). This phenomenon occurs because the increase of temperature reduces water viscosity, a measure of resistance, which leads to alterations in the diffusion of water in the capillaries of the product, favoring the displacement of this fluid from the interior to the periphery (Araujo et al., 2017).

The dependence of the effective diffusion coefficient of canola seeds on the drying air temperature was represented by the Arrhenius expression, as illustrated in Figure 4. 
Table 1. Values for the mean estimated error ( $S E$, decimal), chi-square test $\left(\chi^{2}\right.$, decimal $\left.\times 10^{-4}\right)$, adjusted coefficients of determination $\left(R^{2}, \%\right)$ and mean relative error $(P, \%)$ calculated for the eleven models used to represent the drying kinetics of canola seeds (Brassica napus L.)

\begin{tabular}{|c|c|c|c|c|c|c|c|c|}
\hline \multirow{2}{*}{ Models } & \multicolumn{4}{|c|}{$40 \circ \mathrm{C}$} & \multicolumn{4}{|c|}{$60 \circ \mathrm{C}$} \\
\hline & SE & $x^{2}$ & $P$ & $R^{2}$ & SE & $x^{2}$ & $\mathrm{P}$ & $\mathrm{R}^{2}$ \\
\hline (1) & 0.0073 & 0.53 & 1.42 & 0.9994 & 0.0052 & 0.27 & 1.177 & 0.9997 \\
\hline (2) & 0.0104 & 1.07 & 2.04 & 0.9988 & 0.0070 & 0.50 & 1.370 & 0.9995 \\
\hline (4) & 0.0080 & 0.65 & 1.63 & 0.9992 & 0.0046 & 0.21 & 0.984 & 0.9998 \\
\hline (5) & 0.0125 & 1.56 & 2.26 & 0.9981 & 0.0138 & 1.90 & 3.118 & 0.9977 \\
\hline (8) & 0.0107 & 1.14 & 1.93 & 0.9987 & 0.0103 & 1.06 & 2.007 & 0.9988 \\
\hline (9) & 0.0128 & 1.64 & 2.26 & 0.9981 & 0.0143 & 2.03 & 3.118 & 0.9977 \\
\hline (10) & 0.0099 & 0.98 & 1.86 & 0.9990 & 0.0111 & 1.23 & 2.007 & 0.9988 \\
\hline \multirow[t]{2}{*}{$(11)$} & 0.0131 & 1.72 & 2.29 & 0.9981 & 0.0070 & 0.50 & 1.370 & 0.9995 \\
\hline & $80 \stackrel{\circ}{ } \mathrm{C}$ & & & & 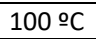 & & & \\
\hline (5) & 0.0234 & 5.46 & 4.347 & 0.9925 & 0.0255 & 6.50 & 6.187 & 0.9920 \\
\hline (6) & 0.0106 & 1.12 & 2.008 & 0.9989 & 0.0146 & 2.13 & 3.310 & 0.9981 \\
\hline (7) & 0.0167 & 2.79 & 3.088 & 0.9969 & 0.0169 & 2.85 & 4.543 & 0.9971 \\
\hline (8) & 0.0187 & 3.48 & 3.303 & 0.9956 & 0.0237 & 5.64 & 5.272 & 0.9937 \\
\hline (9) & 0.0245 & 6.01 & 4.347 & 0.9925 & 0.0267 & 7.15 & 6.187 & 0.9920 \\
\hline (10) & 0.0111 & 1.24 & 1.907 & 0.9988 & 0.0173 & 2.99 & 4.383 & 0.9973 \\
\hline (11) & 0.0105 & 1.10 & 1.903 & 0.9988 & 0.0166 & 2.74 & 4.425 & 0.9973 \\
\hline
\end{tabular}

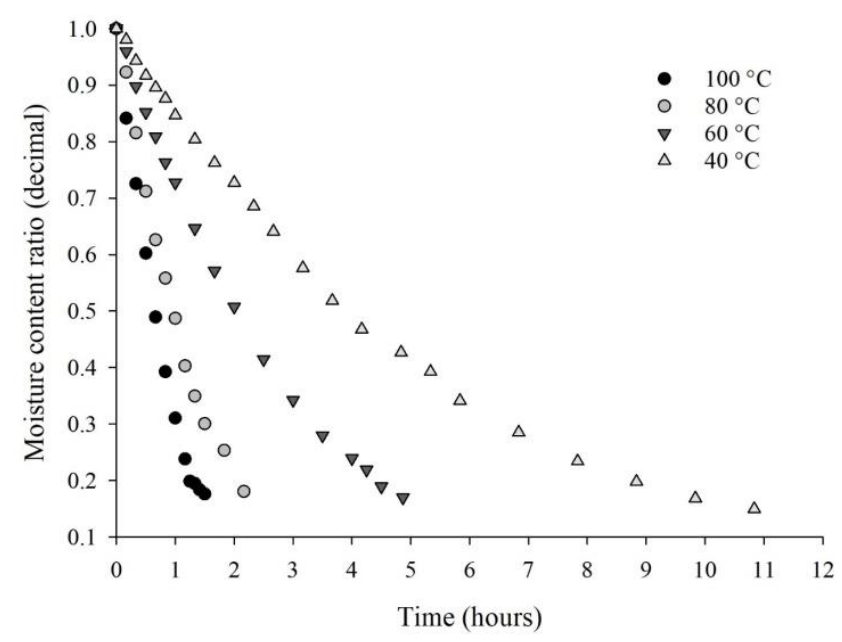

Fig 1. Moisture content ratio of canola (Brassica napus L.) seeds along the drying time under four conditions of air temperature.

Table 2. Akaike information criterion (AIC) and Schwarz's Bayesian information criterion (BIC) values calculated for the eleven models used to represent the drying kinetics of canola (Brassica napus L.) seeds

\begin{tabular}{|c|c|c|c|c|c|c|c|c|}
\hline \multirow{2}{*}{ Models } & \multicolumn{2}{|l|}{$40^{\circ} \mathrm{C}$} & \multicolumn{2}{|l|}{$60^{\circ} \mathrm{C}$} & \multicolumn{2}{|l|}{$80^{\circ} \mathrm{C}$} & \multicolumn{2}{|l|}{$100^{\circ} \mathrm{C}$} \\
\hline & $\mathrm{AIC}$ & $\mathrm{BIC}$ & $\mathrm{AIC}$ & $\mathrm{BIC}$ & AIC & $\mathrm{BIC}$ & $\mathrm{AIC}$ & $\mathrm{BIC}$ \\
\hline Wang and Singh & -127.05 & -123.64 & -126.50 & -124.01 & -64.63 & -63.18 & -62.12 & -60.58 \\
\hline Verma & -150.12 & -148.13 & -127.30 & -130.42 & -44.60 & -41.98 & -52.40 & -51.20 \\
\hline Thompson & -128.40 & -126.32 & -120.38 & -124.41 & -43.90 & -45.23 & -49.26 & -48.36 \\
\hline Page & -152.77 & -149.89 & -131.06 & -133.56 & -67.85 & -99.82 & -65.77 & -64.31 \\
\hline Newton & -133.37 & -131.10 & -94.39 & -92.72 & -53.11 & -52.14 & -51.05 & -50.08 \\
\hline Midilli & -150.61 & -145.28 & -127.12 & -122.96 & -62.98 & -67.56 & -62.30 & -59.88 \\
\hline Logarithmic & -141.88 & -137.34 & -118.74 & -115.40 & -59.59 & -57.65 & -59.36 & -57.42 \\
\hline Henderson and Pabis & -137.05 & -133.64 & -103.41 & -100.91 & -57.66 & -56.21 & -51.90 & -50.45 \\
\hline Two-term exponential & -150.82 & -147.41 & -130.29 & -127.79 & -52.55 & -49.38 & -56.30 & -54.20 \\
\hline Two terms & -152.37 & -146.69 & -128.51 & -124.35 & -38.60 & -36.30 & -52.40 & -51.20 \\
\hline Approximation of diffusion & -150.92 & -147.82 & -129.90 & -122.35 & -53.80 & -52.70 & -55.26 & -58.15 \\
\hline
\end{tabular}




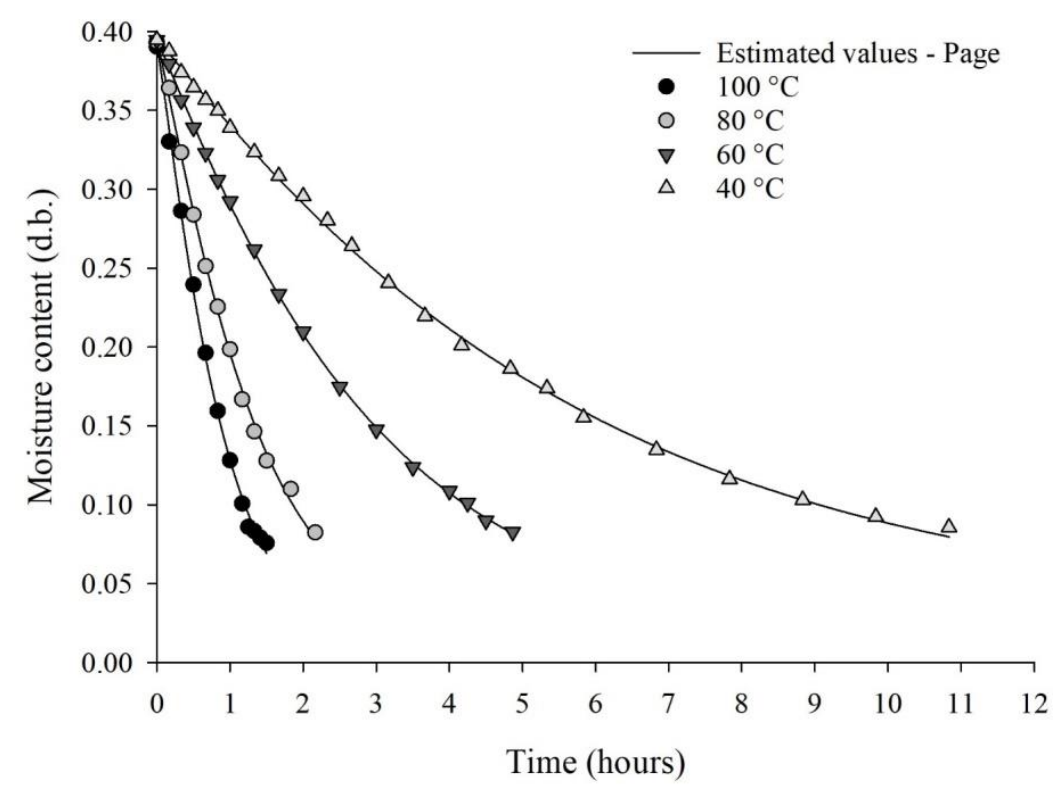

Fig 2. Values of moisture content obtained experimentally and estimated by the Page model for the drying of canola (Brassica napus $\mathrm{L}$.) seeds under the different temperature conditions.

Table 3. Mathematical models used to predict the drying of agricultural products.

\begin{tabular}{|c|c|c|}
\hline Model designation & Model & \\
\hline$R X=1+a \cdot t+b \cdot t^{2}$ & Wang and Singh (Wang and Singh, 1978) & (1) \\
\hline$R X=-a \cdot \exp (-k \cdot t)+(1 \cdot-a) \exp \left(-k_{1} \cdot t\right)$ & Verma (Verma et al., 1985) & (2) \\
\hline$R X=\exp \frac{-a-\left(a^{2}+4 \cdot b \cdot t\right)^{0.5}}{2 \cdot b}$ & Thompson (Thompson et al., 1968) & (3) \\
\hline$R X=\exp \left(-k \cdot t^{n}\right)^{2 \cdot N}$ & Page (Page, 1949) & (4) \\
\hline$R X=\exp (-k \cdot t)$ & Newton (Lewis, 1921) & (5) \\
\hline$R X=a \cdot \exp \left(-k \cdot t^{n}\right)+b \cdot t$ & Midilli (Midilli, 2002) & (6) \\
\hline$R X=a \cdot \exp (-k \cdot t)+c$ & Logarithmic (Yagcioglu et al., 1999) & (7) \\
\hline$R X=a \cdot \exp (-k \cdot t)$ & Henderson and Pabis (Henderson and Pabis, 1961) & (8) \\
\hline$R X=a \cdot \exp (-k \cdot t)+(1 \cdot-a) \exp (-k \cdot a \cdot t)$ & Two-term exponential (Sharaf-Eldee et al., 1980) & (9) \\
\hline$R X=a \cdot \exp \left(-k_{0} \cdot t\right)+b \cdot \exp \left(-k_{1} \cdot t\right)$ & Two terms (Henderson, 1974) & (10) \\
\hline$R X=a \cdot \exp (-k \cdot t)+(1-a) \exp (-k \cdot b \cdot t)$ & Approximation of diffusion (Kassem, 1998) & (11) \\
\hline
\end{tabular}

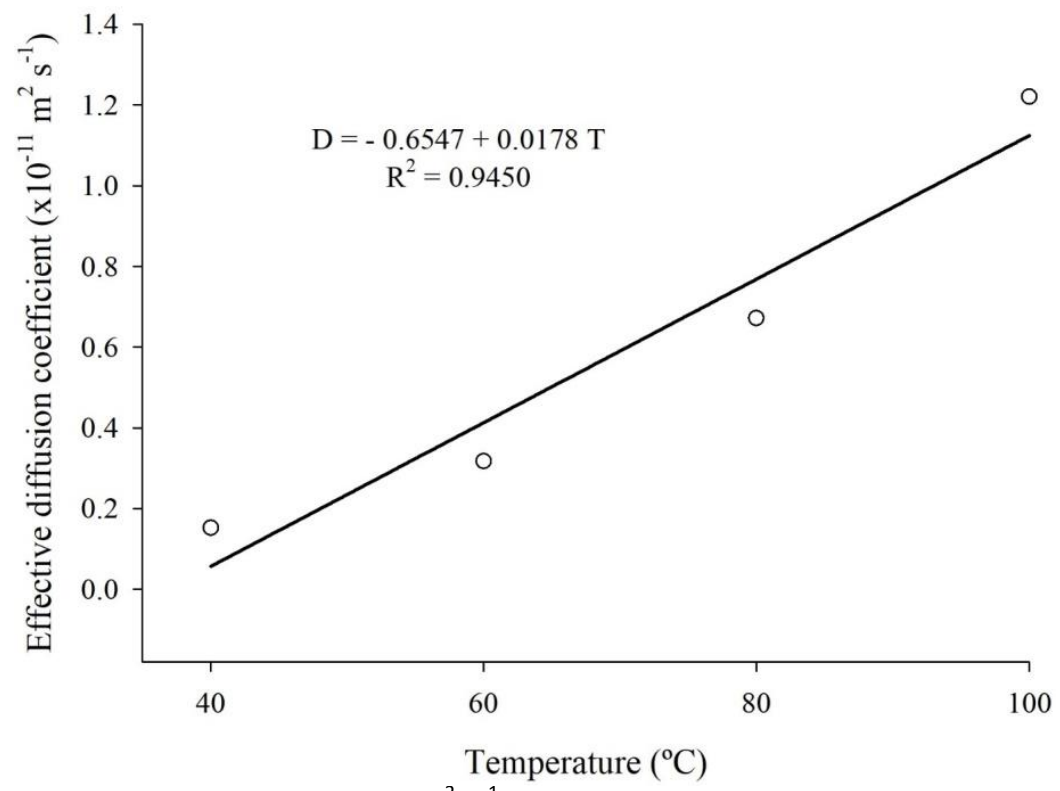

Fig 3. Mean values of effective diffusion coefficient $\left(\mathrm{m}^{2} \mathrm{~s}^{-1}\right)$, obtained for the drying of canola (Brassica napus L.) seeds at temperatures of $40,60,80$ and $100^{\circ} \mathrm{C}$. 


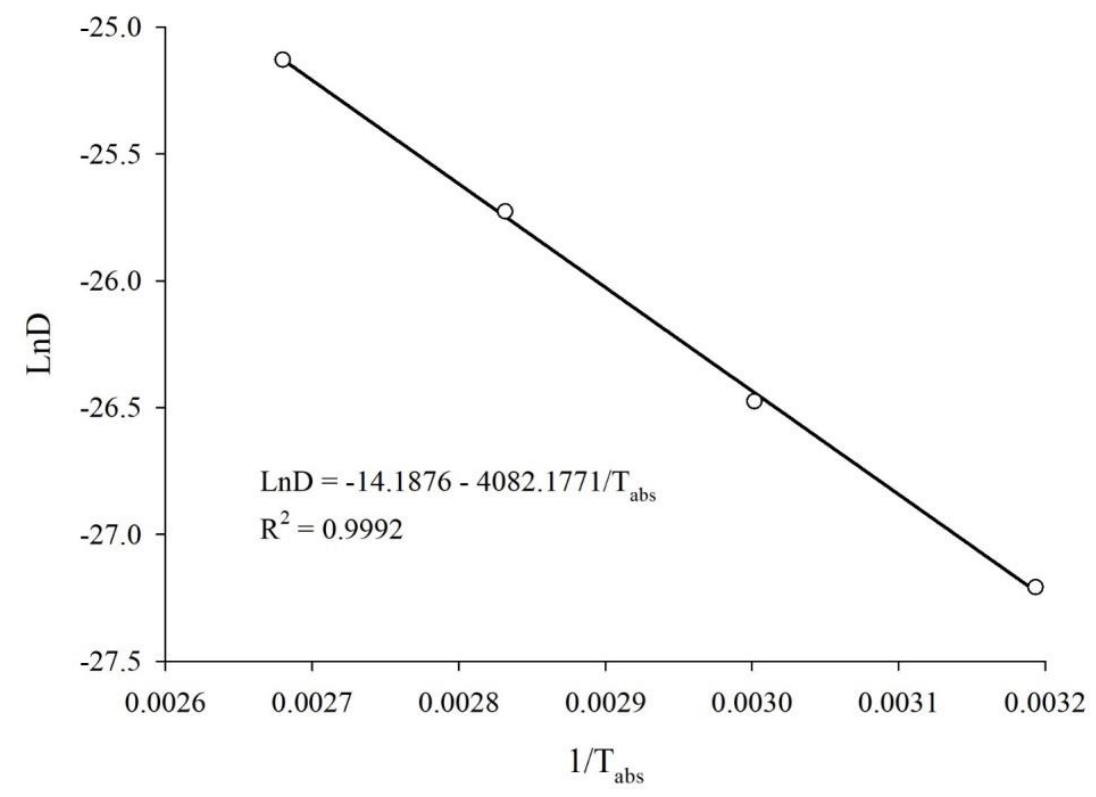

Fig 4. Arrhenius representation of the effective diffusion coefficient obtained for the drying of canola (Brassica napus L.) seeds at temperatures of $40,60,80$ and $100^{\circ} \mathrm{C}$.

\section{Activation energy}

The activation energy obtained for the drying phenomenon of canola seeds was $33.94 \mathrm{~kJ} \mathrm{~mol}^{-1}$ for the temperature range evaluated in this study, of $40,60,80$ and $100{ }^{\circ} \mathrm{C}$. The activation energy indicates the ease with which water molecules overcome the energy barrier during their movement within the product (Corrêa et al., 2007). Hence, the lower the activation energy, the greater the diffusivity of water in the product.

Eq. 16 presents the coefficients of the equation fitted for the effective diffusion coefficient of canola seeds, calculated according to the expression 27.

$$
D=6.8929 \times 10^{-7} \exp \left(-\frac{33939.2204}{R \times T_{a}}\right)
$$

The activation energy found in this study was lower than that obtained by Camicia et al. (2015) for cowpea, $35.04 \mathrm{~kJ}$ $\mathrm{mol}^{-1}$, and higher than the value reported by Oliveira et al. (2012) for corn, $19.09 \mathrm{~kJ} \mathrm{~mol}^{-1}$. These different values of activation energy for the products can be attributed to their physical and biological characteristics (Martins et al., 2015), as well as to the more unstable binding of water to the chemical components of canola, since it is an oilseed crop.

\section{Materials and Methods}

\section{Conduction of the research}

The study was carried out in the Laboratory of Postharvest of Plant Products, at the Federal Institute of Education, Science and Technology of Goiás - Campus of Rio Verde and Campus of Iporá, GO, Brazil. Seeds of the canola hybrid Hyola 430 with initial moisture content of 0.3653 (decimal, d.b.) were used. Drying was carried out in a forced ventilation oven under different controlled conditions of temperature, $40,60,80$ and $100{ }^{\circ} \mathrm{C}$, and relative humidity, $37.15,16.93,8.35,4.41$ and $2.47 \%$, respectively. The seeds were dried on trays without perforations containing approximately $77 \mathrm{~g}$ of product, forming a layer with thickness of around $2 \mathrm{~cm}$.

\section{Drying kinetics}

For the determination of the drying curves and fitting of the models, a final moisture content of $0.080 \pm 0.004 \mathrm{~g}$ (decimal, d.b.) was established. The moisture contents were determined in an oven at $105 \pm 3{ }^{\circ} \mathrm{C}$ for $24 \mathrm{~h}$ (BRASIL, 2009). The hygroscopic equilibrium of canola was determined using three replicates containing $10 \mathrm{~g}$, kept under the specific conditions of drying and periodically weighed until constant weight. The moisture content ratios of the product were determined by Eq. 17:

$$
\mathrm{RX}=\frac{\mathrm{X}-\mathrm{X}_{\mathrm{e}}}{\mathrm{X}_{\mathrm{i}}-\mathrm{X}_{\mathrm{e}}}
$$

where:

$\mathrm{RX}$ - moisture content ratio, dimensionless

$X$ - moisture content of the product at a certain drying time (decimal, d.b.)

$X_{i}$ - initial moisture content of the product (decimal, d.b.)

$X_{e}$ - equilibrium moisture content of the product (decimal, d.b.)

The drying kinetics of canola seeds was represented by the models frequently used to describe the drying of agricultural products (Table 3 ).

\section{Mathematical modeling}

The mathematical models were fitted by means of nonlinear regression analysis using the Gauss-Newton method and were selected considering the mean estimated error (SE), chi-square test $\left(\chi^{2}\right)$, mean relative error $(P)$, and the magnitude of the coefficient of determination $\left(R^{2}\right)$. 


$$
\begin{aligned}
& \mathrm{SE}=\sqrt{\frac{\sum_{i=1}^{\mathrm{n}}{ }^{2}}{\mathrm{DF}}} \\
& \mathbb{Q}^{2}=\sum_{\mathrm{i}=0}^{\mathrm{n}} \frac{(\mathrm{Y}-\hat{\mathrm{Y}})^{2}}{\mathrm{DF}} \\
& \mathrm{P}=\frac{100}{\mathrm{n}} \sum_{\mathrm{i}=1}^{\mathrm{n}}\left(\frac{|\mathrm{Y}-\mathrm{Y}|}{\mathrm{Y}}\right)
\end{aligned}
$$

Where:

$\mathrm{Y}$ - experimental value;

$\hat{Y}$ - value estimated by the model;

$\mathrm{N}$ - number of experimental observations; and

DF - degrees of freedom of the model (number of experimental observations minus the number of coefficients of the model).

In order to select a single mathematical model to describe the drying process, the models that obtained the best fits were subjected to the Akaike information criterion (AIC) and Schwarz's Bayesian information criterion (BIC).

The Akaike criterion (AIC) is used to compare non-nested models or when three or more models are being compared. Lower AIC values reflect better fitting (Akaike, 1974), according to Eq. 21:

$A I C=-2 \cdot \log (L)+2 \cdot p$

where: $p$ is the number of parameters, $\log$ is the value of the logarithm and $L$ is the likelihood function considering the estimates of the parameters.

The Schwarz's Bayesian information criterion (BIC), Equation 22, also considers the degree of parameterization of the model, and likewise, the lower the value of BIC (Schwarz, 1978), the better the fit of the model. It is an asymptotic criterion, whose adequacy is strongly related to the sample size magnitude. In relation to the penalty applied to the number of parameters, it is stricter than that of AIC for small samples.

$B I C=-2 \cdot \log (L)+p \cdot \log (n)$

where: $n$ is the number of observations used to fit the curve.

\section{Effective Diffusion Coefficient (D)}

The model of liquid diffusion for the spheroidal geometric shape, with eight-term approximation, was fitted to the experimental data of drying of canola seeds, according to Eq. 23:

$$
\mathrm{RX}=\frac{\mathrm{X}-\mathrm{X}_{\mathrm{e}}}{\mathrm{X}_{\mathrm{i}}-\mathrm{X}_{\mathrm{e}}}=\sum_{\mathrm{n}=1}^{\infty} \frac{4}{\lambda_{\mathrm{n}}^{2}} \exp \left[-\frac{\lambda_{\mathrm{n}}^{2} \cdot \mathrm{D} \cdot \mathrm{t}}{4} \cdot\left(\frac{2}{\mathrm{r}}\right)^{2}\right]
$$

where:

$D$ - liquid diffusion coefficient, $\mathrm{m}^{2} \mathrm{~s}^{-1}$

$\mathrm{n}$ - number of terms

$r$ - equivalent radius, $m$

$\lambda_{n}$ - roots of the zero-order Bessel equation

The equivalent radius of the seeds was determined by Eq. 24:

$r=\sqrt[3]{\frac{3 \times V_{s}}{4 \times \pi}}$
Where:

$\mathrm{V}_{\mathrm{s}}$ - volume of seeds, $\mathrm{mm}^{-3}$

The volume of each seed $\left(V_{s}\right)$ was obtained by measuring the three orthogonal axes (length, width and thickness) in fifteen seeds at the end of the drying, using digital caliper with resolution of $0.01 \mathrm{~mm}$, according to Eq. 25:

$V_{s}=\frac{\pi \times A \times B \times C}{6}$

where:

A - length, $1.75 \mathrm{~mm}$
B - width, $1.65 \mathrm{~mm}$
C - thickness, $1.63 \mathrm{~mm}$

\section{Activation energy $\left(E_{a}\right)$}

The relationship between the increase in the effective diffusion coefficient and the elevation of the drying air temperature was described by the Arrhenius equation.

$$
\mathrm{D}=\mathrm{D}_{\mathrm{O}} \cdot \exp \left(\frac{-\mathrm{E}_{\mathrm{a}}}{\mathrm{R} \cdot \mathrm{T}_{\mathrm{ab}}}\right)
$$

Where:

$D_{0}$ - pre-exponential factor

$\mathrm{E}_{\mathrm{a}}$ - activation energy, $\mathrm{kJ} \mathrm{mol}^{-1}$

$\mathrm{R}$ - universal gas constant, $8.314 \mathrm{~kJ} \mathrm{kmol}^{-1}$. $\mathrm{K}^{-1}$

$\mathrm{T}_{\mathrm{ab}}$ - absolute temperature

The Arrhenius expression coefficients were linearized by applying the logarithm in the following form:

$$
\mathrm{LnD}=\mathrm{LnD}_{\mathrm{O}}-\frac{\mathrm{E}_{\mathrm{a}}}{\mathrm{R}} \cdot \frac{1}{\mathrm{~T}_{\mathrm{ab}}}
$$

\section{Conclusions}

The Page model fitted best to the data and was selected to describe the drying kinetics of canola seeds.

The effective diffusion coefficient tends to increase with increasing temperature, ranging from $0.153 \times 10^{-11}$ to $1.221 \times 10^{-11} \mathrm{~m}^{2} \mathrm{~s}^{-1}$, being described by the Arrhenius equation and with activation energy of $33.94 \mathrm{~kJ} \mathrm{~mol}^{-1}$.

\section{Acknowledgments}

The authors extend thanks to IF Goiano, CAPES, FAPEG, FINEP and CNPq for their financial support, which was indispensable to the execution of this study

\section{References}

Akaike H (1974) A new look at ${ }^{(23)}$ the statistical model identification. IEEE Trans Auto Control. 19(6):716-723.

Araujo WD, Goneli ALD, Corrêa PC, Hartmann Filho CP, Martins EAS (2017) Modelagem matemática da secagem dos frutos de amendoim em camada delgada. Rev Cienc Agron. 48(1):448457.

Avhad MR, Marchetti JM (2016) Mathematical modelling of the drying kinetics of Hass avocado seeds. Ind Crop Prod. 91(1):76-87.

Babalis SJ, Belessiotis VG (2004) Influence of the drying conditions on the drying constants and moisture diffusivity during the thin-layer drying of figs. J Food Eng. 65(3):449-458. 
Berbert PA, Queiroz DM, Silva JS, Pinheiro Filho JB (1995) Simulation of coffee drying in a fixed bed with periodic airflow reversal. J Agr Eng Res. 60(3):167-173.

Bergamin GT, Martinelli SG, Della Flora MAL, Pedron FDA, Silva LP da, Radünz Neto J (2011) Fontes protéicas vegetais na alimentação da carpa húngara. Cienc Rural. 41(9):1660-1666.

Botelho FM, Hoscher RH, Hauth MR, Botelho SCC. (2018) Cinética de secagem de grãos de soja: influência varietal. Eng Agr. 26(1):13-25.

Botelho FM, Garcia TRB, Viana JL, Botelho SDCC, Sousa AMB de (2015) Cinética de secagem e determinação do coeficiente de difusão efetivo de grãos de sorgo. Rev Bras Milho Sorgo. 14(2):260-272

Brasil- Ministério da Agricultura, Pecuária e Abastecimento. Secretaria de Defesa Agropecuária (2209) Regras para Análise de Sementes. Brasília: MAPA/ACS, 2009. p.399.

Camicia RG da M, Christ D, Coelho SEM, Camicia RF da M (2015) Modelagem do processo de secagem de sementes de feijãocaupi. Rev Caatinga. 28(3):206-214.

Corrêa PC, Resende O, Martinazzo AP, Goneli ALD, Botelho FM (2007) Modelagem matemática para a descrição do processo de secagem do feijão (Phaseolus vulgaris L.) em camadas delgadas. Eng Agric. 27(2):501-510.

Corrêa PC, Resende O, Garin AS, Jaren C, Oliveira GHH (2011) Mathematical models to describe the volumetric shrinkage rate of red beans during drying. Eng Agric. 31(4):716-726.

Dorneles LDNS, Goneli ALD, Cardoso CAL, Silva CB. da, Hauth MR, Oba GC, Schoeninger V (2019) Effect of air temperature and velocity on drying kinetics and essential oil composition of Piper umbellatum L. leaves. Ind Crop Prod. 142(1):1-8.

Fard NS, Abad HHS, Rad AS, Heravan EM, Daneshian J (2018) Effect of drought stress on qualitative characteristics of canola cultivars in winter cultivation. Ind Crop Prod. 114(1):87-92.

Ferreira Junior WN, Resende O, Oliveira DEC de, Costa LM (2018) Isotherms and isosteric heat desorption of Hymenaea stigonocarpa Mart. seeds. J Agr Sci. 10(10):504-512.

Fleddermann M, Fechner A, Röbler A, Bähr M, Pastor A, Liebert $F$, Jahreis $G$ (2013) Nutritional evaluation of rapeseed protein compared to soy protein for quality, plasma amino acids, and nitrogen balance - A randomized cross-over intervention study in humans. Clin Nutr. 32(4):519-526.

Gomes FP, Resende O, Sousa EP, Oliveira DEC, Araújo Neto FR (2018) Drying kinetics of crushed mass of 'jambu': Effective diffusivity and activation energy. Rev Bras Eng Agr Amb. 22(7):499-505.

Henderson SM (1974) Progress in developing the thin layer drying equation. T ASAE. 17(1):1167-1168.

Henderson SM, Pabis S (1961) Grain drying theory: temperature effect on drying coefficient. J Agr Eng Res. 6(1):169-174.

Kassem AS (1998) Comparative studies on thin layer drying models for wheat. In: International Congress on Agricultural Engineering, 13th., Morocco.

Keneni YG, Hvoslef-Eide AT, Marchetti JM (2019) Mathematical modelling of the drying kinetics of Jatropha curcas L. seeds. Ind Crop Prod. 132(1), 12-20.

Krüger CAMB, Silva JAG, Medeiros SLP, Dalmago GA, Sartori CO, Schiavo J (2011) Arranjo de plantas na expressão dos componentes da produtividade de grãos de canola. Pesquisa Agr Brasil. 46(11):1448-1453.

Lewis WK (1921) The drying of solid materials. J Ind Eng Chem. 13(5):427-433.

Lin, L, Allemekinders H, Dansby A, Campbell L, Durance-Tod S, Berger A, Jones P. (2013) Evidence of health benefits of canola oil. Nutr Rev. 71(6):370-385.

Lima LHDS, Braccini AL, Scapim CA, Piccinin GG, Ponce RM (2017) Adaptability and stability of canola hybrids in different sowing dates. Rev Cienc Agr. 48(2):374-380.
Madamba PS, Driscoll RH, Buckle KA (1996) Thin layer drying characteristics of garlic slices. J Food Eng. 29(1):75-97.

Martins EAS, Lage EZ, Goneli ALD, Hartmann Filho CP, Lopes JG (2015) Cinética de secagem de folhas de timbó (Serjania marginata Casar). Rev Bras Eng Agr Amb, 19(3):238-244.

Midilli A, Kucuk H, Yapar Z. (2002) A New model for single layer drying. Dry Technol. 20(7):1503-1513.

Mohapatra D, Rao PS (2005) A thin layer drying model of parboiled wheat. J Food Eng. 66(4):513-518.

Molina Filho L, Pedro MAM, Telis-Romero J, Barbosa SHR (2006) Influência da temperatura e da concentração do cloreto de sódio $(\mathrm{NaCl})$ nas isotermas de sorção da carne de tambaqui (Colossoma macroparum). Cienc Tec Ali. 26(2):453458.

Norton G, Harris JF (1975) Compositional changes in developing rape seed (Brassica napus L.). Planta. 123(2):163-174.

Oliveira DEC, Resende O, Smaniotto TA de S, Campos RC, Chaves TH. (2012) Cinética de secagem dos grãos de milho. Rev Bras Milho Sorgo. 11(2):190-201.

Page GE (1949) Factors influencing the maximum rates of air drying shelled corn in thin layers. West Lafayette: Purdue University.

Quequeto WD, Siqueira VC, Mabasso GA, Isquierdo EP, Leite RA, Ferraz LR, Hoscher RH, Schoeninger V, Jordan RA, Goneli ALD, Martins EAS (2019) Mathematical modeling of thin-layer drying kinetics of Piper aduncum L. leaves. J Agr Sci. 11(8):225235.

Rosa ADS, Blochtein B, Lima DK (2011) Honey bee contribution to canola pollination in Southern Brazil. Sci Agr. 68(2):255259

Sanches AC, Gomes EP, Ramos WB, Mauad M, Santos SD, Biscaro GA (2014) Produtividade da canola sob irrigação e doses de adubação nitrogenada. Rev Bras Eng Agr Amb. 18(7):688-693.

Sharaf-Eldeen YI, Blaisdell JL, Hamdy MY (1980) A model for ear corn drying. T ASAE. 23(1):1261-1265.

Siles JA, González-Tello P, Martín MA, Martín A (2015) Kinetics of alfalfa drying: Simultaneous modelling of moisture content and temperature. Bio Eng. 129(1):185-196.

Singh AK (2011) Castor oil-based lubricant reduces smoke emission in two-stroke engines. Ind Crop Prod. 33(2):287-295.

Souza DG, Resende O, Moura LCD, Junior FWN, Andrade JWDS (2019) Drying kinetics of the sliced pulp of biofortified sweet potato (Ipomoea batatas L.). Eng Agr. 39(2):176-181.

Schwarz G (1978) Estimating the dimension of a model. Ann Stat. 6(1):461-464.

Smaniotto TADS, Resende O, Sousa KAD, Oliveira DEC de, Campos RC (2017) Drying kinetics of sunflower grains. Rev Bras Eng Agr Amb. 21(3):203-208.

Thompson TL, Peart RM, Foster GH (1968) Mathematical simulation of corn drying: a new model. T ASAE 11(4):582-586.

Verma LR, Bucklin RA, Endan JB, Wratten FT (1985) Effects of drying air parameters on rice drying models. T ASAE. 28(1):296-301.

Yagcioglu A, Degirmencioglu A, Cagatay F (1999) Drying characteristics of laurel leaves under different conditions. In: International Congress on Agricultural Mechanization and Energy, 7th. Adana. Proceedings... Adana: Cukurova University.

Wang CY, Singh RP (1978) Use of variable equilibrium moisture content in modeling rice drying. T ASAE. 11(1):668-672. 